\title{
The Galvanic Corrosion Behavior of Phosphated Carbon Steel Used at Carabiners Manufacturing
}

\begin{abstract}
DIANA PETRONELA BURDUHOS NERGIS ${ }^{1}$, CARMEN NEJ NERU'1, DUMITRU DORU BURDUHOS NERGIS ${ }^{1}$, CRISTIAN SAVIN¹, ANDREI VICTOR SANDU ${ }^{1,2}$, STEFAN LUCIAN TOMA*, COSTICA BEJ INARIU ${ }^{1,2 *}$

${ }^{1}$ Gheorghe Asachi Technical University of Iasi, Faculty of Materials Science and Engineering, 67 D. Mangeron Str., 700050 Iasi, Romania

2Romanian Inventors Forum, 3 Sf. P. Movila Str., 700089 Iasi, Romania

The carabiners are metallic links used to quickly connect the components of personal fall arrest equipment. Because these systems are used in corrosive environments, the carabiners must possess good corrosion resistance properties. In order to improve these properties, a phosphate layer was chemically deposited by converting on the carabiner material surface. This paper presents the microscopic analysis of the phosphated layer and the galvanic corrosion behavior of phosphated carbon steel, coupled to duralumin and initial carbon steel. Corrosion resistance has been studied for Black Sea water and fire extinguishing solution.
\end{abstract}

Keywords: galvanic corrosion, carbon steel, phosphated layer, Black Sea water, extinguish solution

Accidents resulting from height falls have a high contribution to the total number of work accidents with are usually classified as those with very serious consequences or with irreversible effects on workers health or as fatal accidents [1, 2].

A literature review highlighted the fact that, even the main goal of multiple strategies was to reduce the number of human accidents, the high fall related accidents are still among the most common deadly work accidents [3].

Because high falls-related accidents continued to occur, it is clear that the working environment risk factors are influencing not just the workers, butalso negatively affects the properties of the individual protective equipment [4].

The individual fall arrest or fall restrain equipments includes all the elements and components (connectors, ropes, positioning belts, fall stops etc.) linked in a certain system, used in order to prevent or stop the heights fall [5].

There are two types of connectors used in a individual fall protection equipment, namely: hooks and carabiners [6]. A carabiner is a metallic link with an inward opening gate, used as a link between the rope and another component of fall arrest system, during climbing [7]. The schematic representation of a carabiner is presented in the figure 1 .

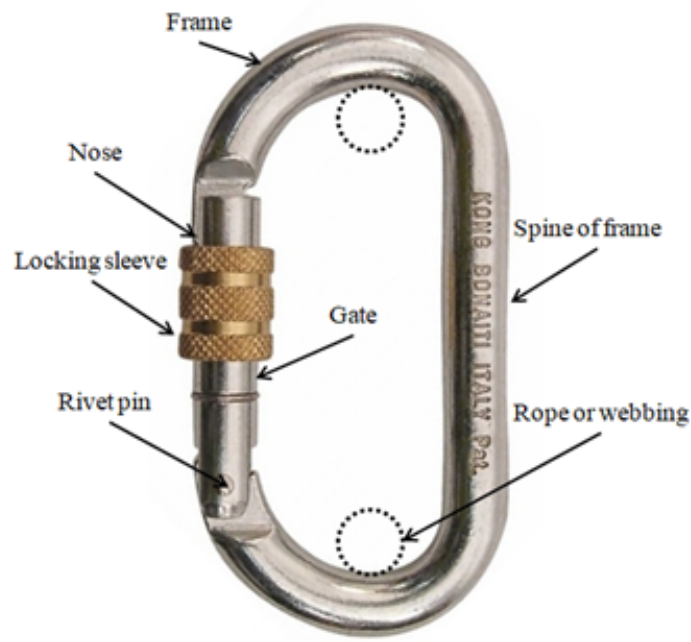

Fig. 1. Elements components of a carabiner used at fall arrest and fall restrain equipments [8]
The most common materials used for carabiner body manufacturing are steel and aluminum alloys. The gate is made from a hollow tube which is attached to the body by a rivet pin and driven by a spring. This arch is usually made of stainless steel. The carabiner gate as well as the locking system is generally made of aluminum alloys or polymeric materials [9-11].

Due to its high mechanical properties, in areas such as caving, diving, rescue operations or construction, steel carabiners are generally used [12]. Due to their various use, carabiners come into contact with different corrosive substances, such as saltwater or fire extinguishing solution [13].

In order to improve the corrosion resistance properties of carbon steel carabiners, a layer of insoluble phosphates chemically bonded to the body carabiner material surface was deposited. Figure 2 presents the surface of the initial and phosphated carbon steel samples used in this study.
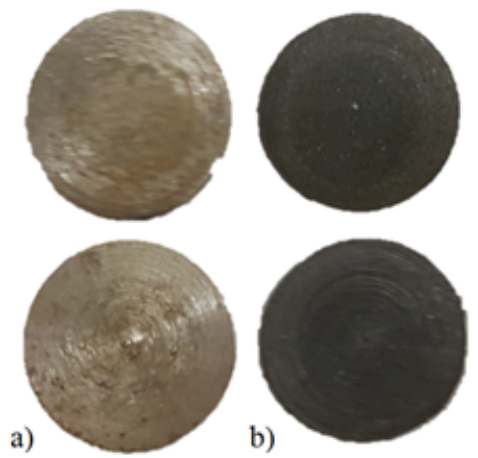

Fig. 2. Surface of carbon steel samples: a) initial samples and

b) phosphated samples

Phosphate conversion coating is a process used for the pretreatment of metallic surfaces, which consist in a layer of crystals of iron, manganese or zinc insoluble phosphates. The main fields of application of phosphating are: corrosion protection along with organic coatings, for example, polymeric paints or layers, cold plastic deformation or corrosion protection along with oils or no further treatment [14-17].

Corrosion can be defined as the phenomenon of superficial or in-depth degradation of a material, usually metal, under the influence of physicochemical factors of the environment [18].

Galvanic corrosion refers to the materials degradation in corrosive environments of systems made up to two

*email: stltoma@gmail.com; costica.bejinariu@tuiasi.ro 
different metals in direct contact or interconnected by an electronic conductor. This type of corrosion occurs frequently at weld joints, iron and zinc contact (galvanized steel sheet) or copper and brass from heat exchangers [19].

From the corrosive attack point of view, galvanic corrosion is a type of local corrosion and is at the same time an electrochemical corrosion due to the electrochemical mechanism of degradation of metallic material exposed to the corrosive environment [20].

Local corrosion highly influences the mechanical properties of the parts, although only certain sections are weakened. Because the total strength of a partor structure highly depends of the weakest section, local corrosion is very dangerous and involves high economic cost [21].

At the contact between two different metals, the metal with a more negative corrosion potential corrodes more intensely and represents the anode of the galvanic couple, the one with less negative corrosion potential becomes the cathode of the bimetallic system [22].

The corrosion due to passage of a electrical current into the galvanic couple is determined by:

- anodic dissolution:

$(-) M \rightarrow M^{Z+}+$ ze- of the metal with a more negative corrosion potential;

- and depolarizer reduction (on the cathode - on the metal with a less negative corrosion potential), which can be:

- hydrogen ions: (-) $\mathrm{H}^{+}+\mathrm{e}^{-} \rightarrow \mathrm{H}$ rarely, or reducing more commonly

- oxygen dissolved in water $(+) \mathrm{O}_{2}+2 \mathrm{H}_{2} \mathrm{O}+4 \mathrm{e}^{-} \rightarrow 4 \mathrm{HO}^{-}$

The parameters that characterize the galvanic corrosion of a system with a pair of metals (the potential of couples $-E_{\text {couplu }}$ and the current density for couple $-j_{\text {couple }}$ ) are influenced by a number of factors, such as: the difference betw een the pair potentials of the couple's electrodes, the quality of the electrical connection between metals, the electrolyte conductivity, the two electrodes exposed areas ratio, the distance between the electrodes, the electrolyte degree of oxygenation, the metallurgical composition etc. [23].

For galvanic corrosion evaluation, the potentiodynamic measurements and the linear polarization curves are used.

The coupling of two different metals can be used to protect a material from corrosion degradation by coupling the metal to a lesser noble metal which will be corroded. The process is called cathodic protection or protection with sacrificial anodes [24]. The sacricial anodes for steel protection are currently made of three metals: zinc, magnesium and aluminum. Zinc has a potential of about $0.25 \mathrm{~V}$ of steel, a sufficiently negative value to provide cathodic steel protection in low corrosive environments. Magnesium, due to its more electronegative potential, provides steel protection even in environments with high resistivity. Compared to zinc and magnesium, aluminum has some advantages as protective anodes (a fairly negative potential and a lower electrochemical equivalent), but the highly passivity of aluminum restrain its area of applicability [19].

By increasing the ratio between the cathode and anode area, the anode dissolution rate increases and the cathode corrosion rate decreases. It can therefore be admitted that the speed of a galvanic corrosion process of a less noble metal increases, when coupled with a noble material, with the increase of the exposed area [25].

\section{Experimental part}

\section{Phosphate layer analysis}

The deposition of trizinc phosphate tetrahydrate on carbon steel surface by phosphate conversion coating 216 process consists of three main steps: degreasing, pickling and phosphating.

The main goal of the first stage is to chemically degrease the sample surface using a alkaline solution with the following parameters: $85^{\circ} \mathrm{C}$ solution temperature, $\mathrm{pH}=11$ $\div 12$, the samples must be submerged for $10 \mathrm{~min}$. The alkaline chemical degreasing solution consists of sodium hydroxide, trisodium phosphate, sodium carbonate, sodium silicate and surfactant detergent. After first stage, the samples are transferred to the pickling solution composed of hydrochloric acid, hexamethylenetetramine and sodium sulphate. During this stage the samples are submerged for $20 \mathrm{~min}$ in the solution at room temperature $\left(20-25^{\circ} \mathrm{C}\right)$.

The deposition itself take place during the third stage, when the samples are maintained for $30 \mathrm{~min}$ in the phosphated solution at $90^{\circ} \mathrm{C}$ which contains phosphoric acid, nitric acid, zinc, sodium tripolyphosphate, sodium hydroxide and sodium nitrite.

Thickness measurements and microstructural analysis of the phosphated layer obtained were conducted by means of scanning electron microscopy

Observation of the phosphate layer and its thickness measurement were determined using the electron scanning microscope (SEM VegaTescan LMH II).

\section{Galvanic corrosion}

In order to check and calculate the corrosion potential of the phosphated layers, multiple systems consist in C45 phosphated samples, C45 initial samples and duralumin were analyzed in two different types of corrosive environments: salt water and extinguishing solution.

The chemical composition according to standard [26] of C45 carbon steel is shown in table 1. Table 2 presents the chemical composition of duralumin samples. Table 3 presents the used carbon steel samples chemical composition.

Table 1

CHEMICAL COMPOSITION OF STANDARD C45 CARBON STEEL

\begin{tabular}{|c|c|c|}
\hline \multirow{2}{*}{ Chemical element } & \multicolumn{2}{|c|}{$\%$} \\
\cline { 2 - 3 } & Minim & Maxim \\
\hline $\mathrm{C}$ & 0.42 & 0.50 \\
\hline $\mathrm{Mn}$ & 0.50 & 0.80 \\
\hline $\mathrm{P}$ & & 0.04 \\
\hline $\mathrm{S}$ & & 0.045 \\
\hline $\mathrm{Si}$ & 0.17 & 0.37 \\
\hline $\mathrm{Ni}$ & & 0.30 \\
\hline $\mathrm{Cr}$ & & 0.30 \\
\hline $\mathrm{Cu}$ & & 0.30 \\
\hline $\mathrm{As}$ & & 0.05 \\
\hline
\end{tabular}

Table 2

CHEMICAL COMPOSITION OF DURALUMIN SAMPLES

\begin{tabular}{|c|c|c|}
\hline \multirow{2}{*}{$\begin{array}{c}\text { Chemical } \\
\text { element }\end{array}$} & \multicolumn{2}{|c|}{$\%$} \\
\cline { 2 - 3 } & Minim & Maxim \\
\hline $\mathrm{Si}$ & 0.20 & 0.08 \\
\hline $\mathrm{Fe}$ & & 0.70 \\
\hline $\mathrm{Cu}$ & 3.50 & 4.50 \\
\hline $\mathrm{Mn}$ & 0.40 & 1.0 \\
\hline $\mathrm{Mg}$ & 0.40 & 1.0 \\
\hline $\mathrm{Cr}$ & & 0.10 \\
\hline $\mathrm{Zn}$ & & 0.25 \\
\hline $\mathrm{Ti}$ & & 0.25 \\
\hline Others & & 0.05 \\
\hline
\end{tabular}

The corrosion behavior was achieved by rapid electrochemical tests, respectively by dynamic http://www.revistadechimie.ro 
Table3

CHEMICAL COMPOSITION OF C45 CARBON STEEL SAMPLES

\begin{tabular}{|c|c|c|c|c|c|c|c|}
\hline Chemical element & Fe & C & Si & Mn & P & Cu & Cr \\
\hline$\%$ & balance & 0.45 & 0.22 & 0.98 & 0.02 & 0.15 & 0.17 \\
\hline
\end{tabular}

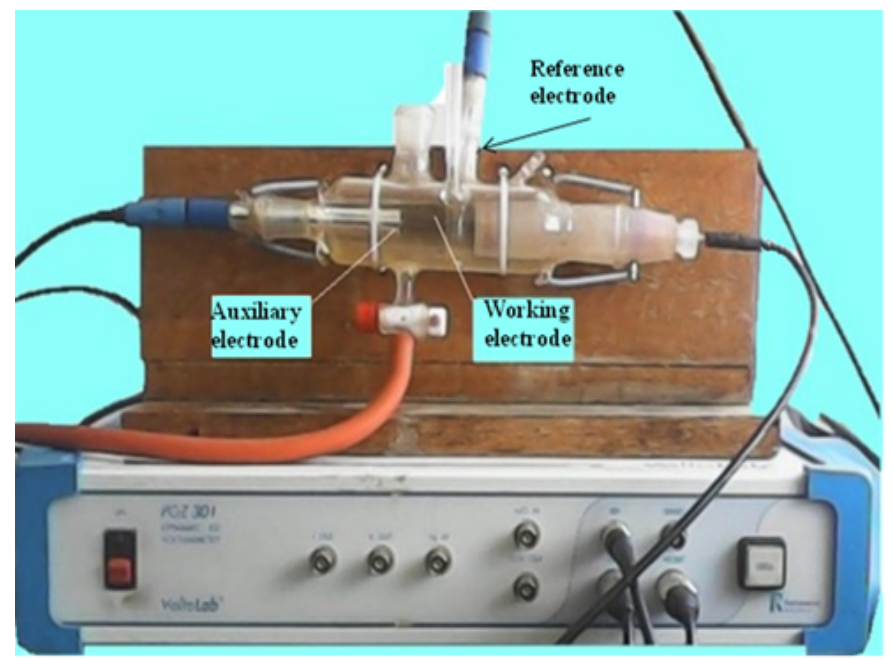

Fig.3. The potentiostat and the three electrode special cell

potentiometry. The potential measurement in open circuit and the dynamic polarizations were performed by means of a dynamic electrochemical system VoltiLab 40 (PGZ301) (Radiometer Analytical SAS - France). For thuse measurements, a three-electrode special cell, presented in next to the potentiostat in figure 3 , was used.

The used electrodes (work electrode) were cutted in the form of discs $(10 \mathrm{~mm}$ in diameter and $2 \mathrm{~mm}$ in thickness) being fixed inside the cell by means of a screw and a teflon gasket for sealing. Through this positioning, the surface of the electrode exposed to the corrosion environment was planar and circular without edges or peaks. The surface exposed to corrosion environment was in all cases equal to $0.283 \mathrm{~cm}^{2}$. The initial samples were polished by means of a SiC polishing paper to 2500 grit, degreased and washed with distilled water. The phosphate samples were only washed with distilled water. A platinum electrode was used as an auxiliary electrode and as a reference, a saturated calomel electrode. The measurements were made at 25 ! with a scanning potential of $0.5 \mathrm{mV} / \mathrm{s}$ potential.

\section{Results and discussions}

Following the phosphating process, a film of triazine phosphate tetrahydrate was chemically bonded to the base material surface, in this study carbon steel. Figure 4 shows the phosphate layer and crystal dendrites obtained by adding sodium hydroxide to the phosphate solution.

The phosphate coating thickness may vary between 0.5 and $40 \mu \mathrm{m}$ and depends on multiple factors, such as: the processing parameters, solution composition or sample surface characteristics (roughness, cleanliness). The base metal chemical composition determines the phosphate crystals orientation and the final phosphate layer structure $[27,28]$.

The studied carbon steel samples present an average

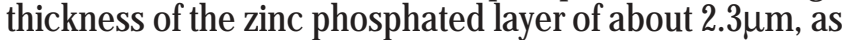
can be seen in figure 5 , with a substrate of about 1.6um.

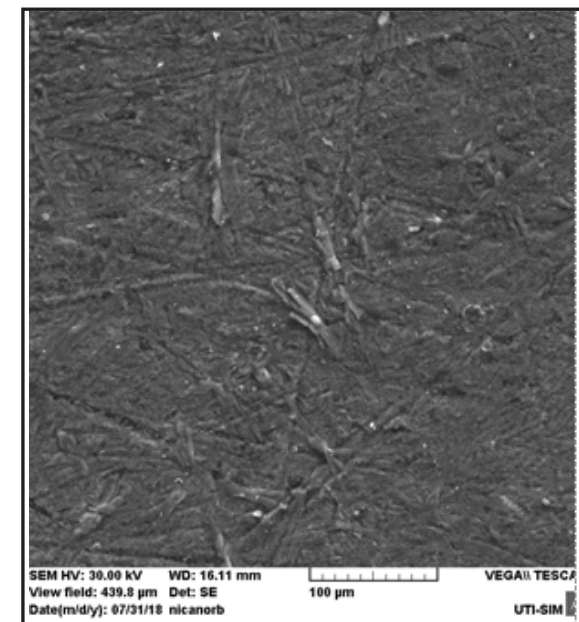

(a)

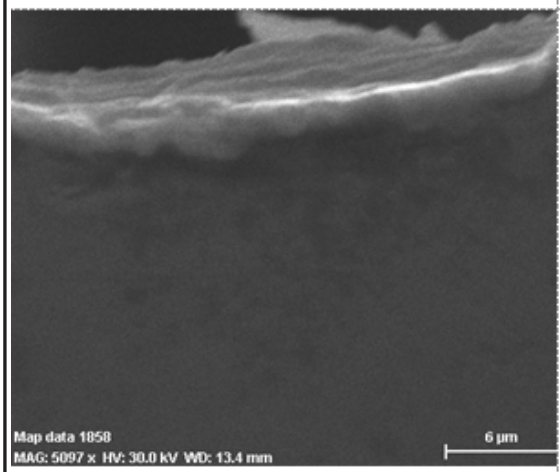

(c)

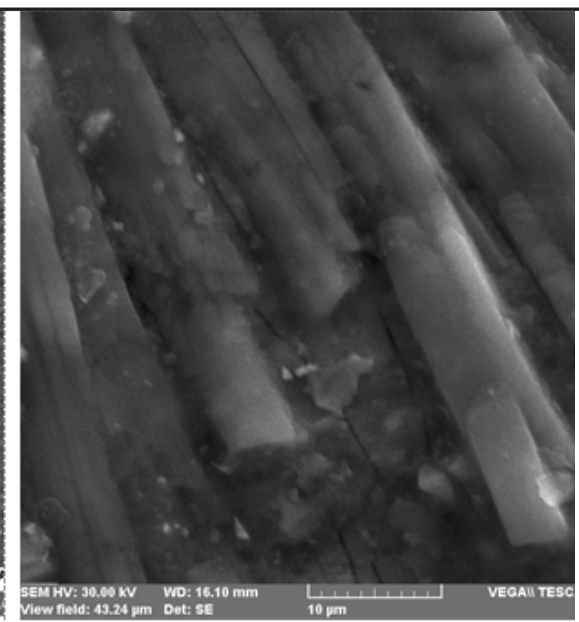

(b)

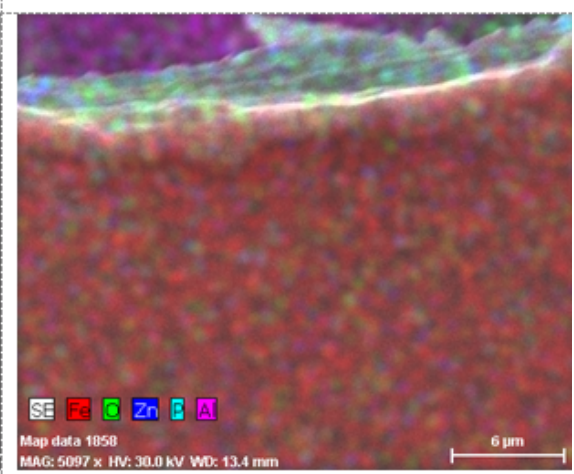

(d)
Fig. 4 Phosphated layer structure,

(a) SEM microstructure, $100 \mu \mathrm{m}$;

(b) SEM mictrostructure, $10 \mu \mathrm{m}$;

(c) EDX, $6 \mu \mathrm{m}$; (d) EDX, $6 \mu \mathrm{m}$; 


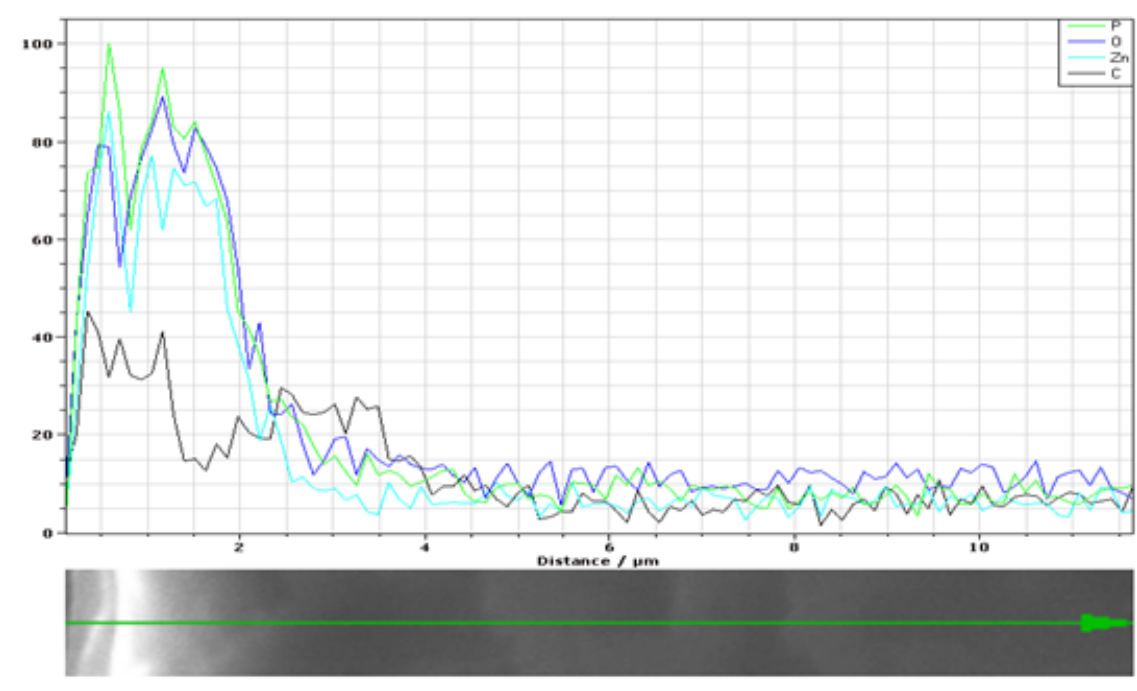

Fig. 5. Zinc phosphated layer thickness

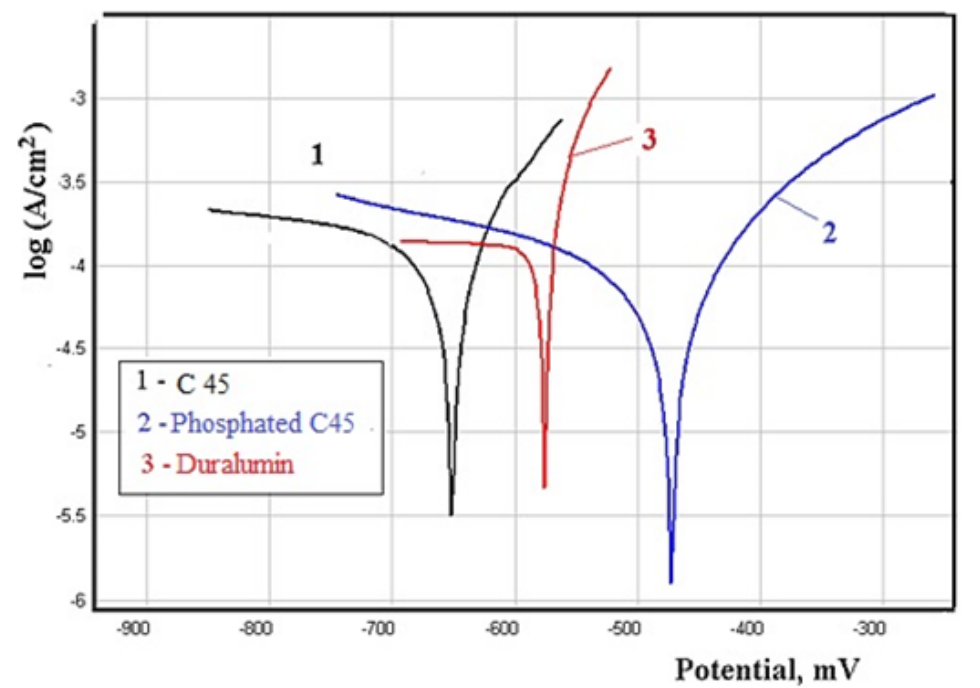

Fig. 6. Galvanic couple of samples in Black Sea water

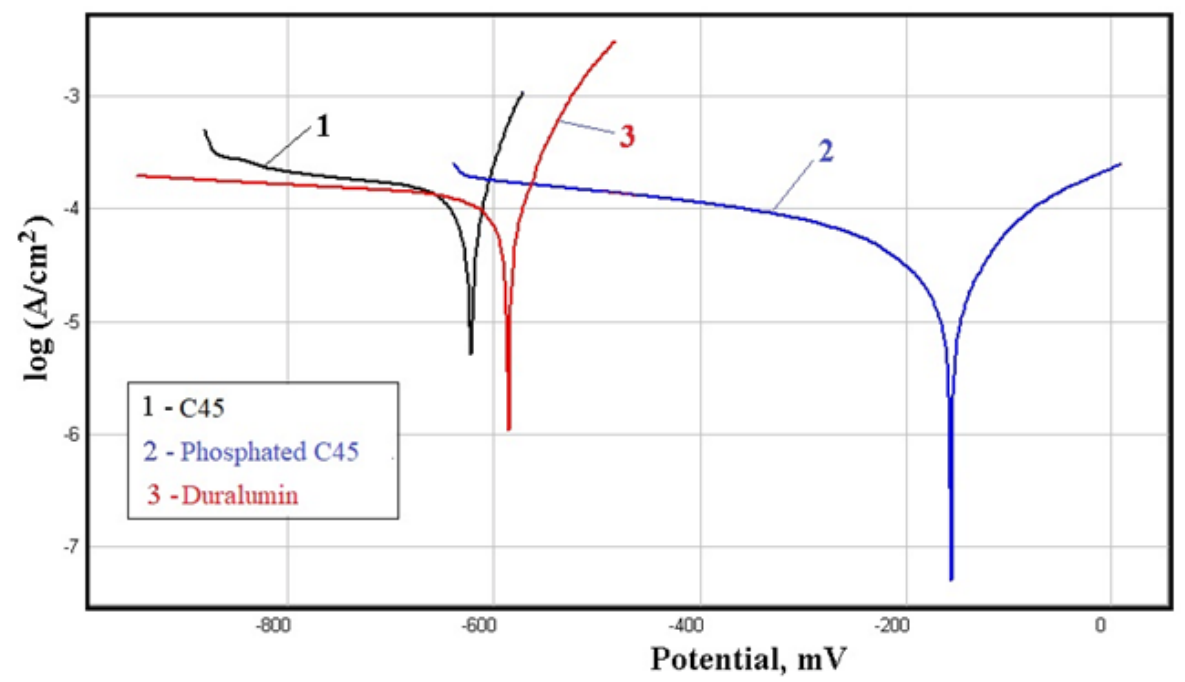

Fig. 7. Galvanic couple of samples in fireextinguishing solution

The corrosion resistance of phosphate and initial carbon steel samples was measured by recording the linear polarization curves in seawater and the fire-extinguishing solution and processed by means of Evans diagrams. Through the phosphating process, a corrosion resistance increase was obtained by $33 \%$ for contact with fireextinguishing solution, and upon $46 \%$ for contact with Black Sea water.

Based on the obtained polarization curves, the galvanic corrosion parameters were evaluated according to the procedure described above for the non-coupled alloys in both corrosion environments. The galvanic corrosion behavior for couplings in Black Sea water can be seen in figures 6 and 7 for fire-extinguishing solution for all three studied alloys.

Galvanic corrosion parameters for the analyzed couplings in two corrosion environments are presented in table 4.

As can be seen from figures 6 and 7 and the value differences between the curves presented in table 4 , the couple current densities are within the same order of magnitude as those obtained for the non-coupled alloys in the same corrosion environment, but these are added (for the corroded material) or reduced (in noble material case) to the density values of non-coupled alloys. 
Table 4

GALVANIC PARAMETERS FOR ALLOYS COUPLES IN BLACK SEA WATER AND FIRE-EXTINGUISHING SOLUTION

\begin{tabular}{|c|c|c|c|c|}
\hline \multirow{2}{*}{ Corrosion environment } & Galvanic parameters & C45/Duralumin & $\begin{array}{c}\text { Phosphated C45/ } \\
\text { Duralumin }\end{array}$ & C45/Phosphated C45 \\
\hline \multirow{2}{*}{ Black Sea water } & $E_{\text {cuplu }}, \mathrm{mV}$ & -625 & -568 & -622 \\
\cline { 2 - 5 } & $\mathrm{J}_{\text {cump }}, \mathrm{mA} / \mathrm{cm}^{2}$ & 0,138 & $-0,140$ & 0,168 \\
\hline \multirow{2}{*}{$\begin{array}{c}\text { Fire-extinguishing } \\
\text { solution }\end{array}$} & $\mathrm{E}_{\text {suplu }}, \mathrm{mV}$ & -611 & -563 & -603 \\
\cline { 2 - 5 } & $\mathrm{J}_{\text {cuplu, }} \mathrm{mA} / \mathrm{cm}^{2}$ & 0,100 & $-0,167$ & 0.182 \\
\hline
\end{tabular}

Red - the corroded material.

In case of initial/C45 phosphate samples coupling, the current densities value is higher than that obtained for initial/duralumin samples couple or C45 phosphate/ duralumin samples couple. The existence of this galvanic coupling becomes dangerous if the phosphated layer presents thickness irregularities poor adhesion, because the corrosion is amplified in the unphosphated areas.

\section{Conclusions}

The surface of phosphated layer presents crystal dendrites formed due to the introduction of $\mathrm{NaOH}$ flakes in the phosphating solution. The average thickness of tetrahydrate triazine phosphate layer has $2.3 \mu \mathrm{m}$ and a substrate of about $1.6 \mu \mathrm{m}$.

According to our results the $\mathrm{C} 45$ phosphate steel is the noble material in both types of coupling, with duralumin or initial sample, the corrosion speed rate in both environments is lower than obtained for the un-coupled sample.

The corrosion speed rate of initial sample increase in both types of coupling and, also, for both types of corrosive environments, i.e. Black Sea water and fire extinguishing solution.

Due to the chemically deposited triazine phosphate tetrahydrate layer on C45 steel surface, the material used in carabiners manufacturing, during phosphate conversion coating, the corrosion resistance properties increase significantly, supporting the main idea that by improving a personal equipment properties a human life can be saved.

\section{References}

1. BABUT, G.B., MORARU, R.I., Quality - Access to Success, 19, no. 166, 2018, p. 133.

2. BEJ INARIU, C., DARABONT, D.C., BACIU, E.R., GEORGESCU, I.S., BERNEVIG-SAVA, M.A., BACIU, C., Sustainability, 9, 2017, p. 1263.

3. CRACIUN, N., Cercetari privind comportarea echipamentelor individuale de protecpe (eip) pentru lucrul la înãlpme la acpinea sinergicã a factorilor de risc, PhD Thesis, Gheorghe Asachi Technical University from lasi, 2016.

4. EVANS, T., TRUEBE, S., A Review of Webbing Anchor Research, International Technical Rescue. Symposium, Portland, Oregon, 2015. 5. POP, M., Think Outside the Box in Fall Protection, Workplace Safety Management Forum, 2013.

6. BRITISH STANDARDS INSTITUTION, EN 362, Personal protective equipment against falls from a height -Connectors, BSI Standards Limited, 2004.

7. BURDUHOS NERGIa , D.P., NEJ NERU, C., ACHITEI, D.C., CIMPOIEäU, N., BEJ INARIU, C., Structural Analysis of Carabiners Materials Used at Personal Protective Equipments, IOP Conference Series: Materials Science and Engineering, 374, no. 1, 2018, Art. no. 012040.

8. BRITISH STANDARDS INSTITUTION, EN 12275, Mountaineering equipment-Connectors -Safety requirements and test, BSI Standards Limited, 1998.
9. BLACKFORD, J.R., Materials in mountaineering, Jenkins $M$ (ed) Materials in sports equipment, Woodhead, 2003, p. 279.

10. BLAIR, K.B., CUSTER, D.R., GRAHAM, J.M., OKAL, M.H., Sports Eng., 8, 2005, p. 107.

11. BRIGHT, C.M., A Hystory of Rock Climbing Gear Technology And Standards, Mechanical Engineering Udergraduate Honor Theses, 2014. 12. SCOTT, V., Design of a Composite Carabiner for Rock Climbing, Final Year Project, Mechanical Engineering, Imperial College London, 2008.

13.*** UIAA, UIAA 121 Mountaineering and Climbing Equipment Connectors, Union Internationale des Associations d'Alpinisme, 2004. 14. BEJ INARIU, C., SANDU, A.V, BACIU, C., SANDU, I., TOMA, S.L., SANDU, I.G., Rev. Chim. (Bucharest), 61, no. 10, 2010, p. 961.

15. LAZAR, P., BEJ INARIU, C., SANDU, A.V., CAZAC, A.M.; CORBU, O., SANDU, I.G., PERJU, M. C., Corrosion Evaluation of Some Phosphated Thin Layers on Reinforcing Steel, International Conference on Innovative Research - ICIR Euroinvent, 209, 2017, p. 12025.

16. SANDU, A.V., BEJ INARIU, C., NEMTOI, G., SANDU, I. G., VIZUREANU, P., IONITA, I., BACIU, C., Rev. Chim. (Bucharest), 64, no. 8, 2013, p. 825.

17. SANDU, A.V., CIOMAGA, A., NEMTOI, G., BEJ INARIU, C., SANDU, I., J. Optoelectron. Adv. Mater, 14, 2012, p. 704.

18. BÃLATU M.S., VIZUREANU P., CIMPOE'U R., ABDULLAH M.M.A.B., SANDU A.V., Rev. Chim. (Bucharest), 67, no. 10, 2016, p. 2100.

19. PHILIPPE M., Corrosion Mechanisms in Theory and Practice, Marcel Dekker Inc., New York, 2002.

20. CIMPOESU, N., AXINTE, M., HANU, R.C., NEJNERU, C., ACHITEI, D.C., STANCIU, S, J ournal of Optoelectronics and Advanced Materials, 12, no. 8, 2010, p. 1772.

21. JOE H., NEIL G. THOMPSON, D.C, Electrochemical Test Methods, NACE International Book Publications, 1998, p. 42.

22. NEJNERU, C., PERJU, M.C., SANDU, A.V., AXINTE, M., QUARANTA, M., SANDU, I., COSTEA, M., ABDULLAH, M.M.A.B., Rev. Chim. (Bucharest), 67, no. 6, 2016, p. 1191.

23. ROTHWELL, N., TULLMIN, M., Machine and Systems Condition Monitoring Series: The Corrosion Monitoring Handbook, Coxmoor Publishing Company, 2000, pp. 27.

24. AELENEI, D.M., Studiul coroziunii unor materiale dentare, PhD Thesis, Faculty of Materials Science and Engineering, Gh. Asachi Technical University of lasi, 2009.

25. BRITISH STANDARDSINSTITUTION, EN 10083-2, Steels for quenching and tempering. Technical delivery conditions for non alloy steels, BSI Standards Limited, 2006.

26. SANDU, A.V., CIOMAGA, A., NEMTOI, G., BEJ INARIU, C., SANDU, I., Microsc. Res. Tech., 75, 2012, p. 1711.

27. SANDU, A.V., CODDET, C., BEJ INARIU, C., J. Optoelectron. Adv. Mater., 14, 2012, p. 699.

28. SANDU, A.V., CODDET, C., BEJ INARIU, C., Rev. Chim., (Bucharest), 63, no. 4, 2012, p. 401.

Manuscript received: 16.09 .2018 